\title{
Household Preparedness to Reducing Landslide Disaster Risk in Sepakung Village
}

\author{
Yohanes Dwi Anugrahanto ${ }^{1}$, Dewi Liesnoor Setyowati ${ }^{2}$, Erni Suharini ${ }^{3}$ \\ ${ }^{1}$ Postgraduate, ${ }^{2}$ Department Geography, ${ }^{3}$ Department Geography Education Universitas Negeri Semarang, \\ Semarang City, Indonesia. \\ Corresponding Author: Dewi Liesnoor Setyowati
}

\begin{abstract}
Landslides are one of the natural disasters that often occur in Indonesia. Throughout 2019, Indonesia experienced 1483 landslides. Indonesian people need to have preparedness in dealing with disasters. Sepakung village is included in a landslide-prone area in Semarang regency, Central Java. This study aims to analyze the preparedness of the people of Sepakung village who live around landslideprone points. The research method used is quantitative with a descriptive percentage analysis technique. The population of this research is the residents of Sepakung village. The sampling technique used is purposive sampling. Data collection techniques using observation, questionnaires, and documentation. The data processing results show that the experience of dealing with landslides for the residents of Sepakung village is quite good. This is shown from the average descriptive percentage score reaching 65.909091. The attitude of the respondent's vigilance is included in the very good category, with a descriptive score of the percentage getting $85 \%$. All respondents in this study agreed that awareness of landslides needs to be increased during the rainy season. Knowledge of landslides that are owned needs to be increased again, especially for knowledge about the signs of landslides, disaster mitigation, early warning systems, and evacuation routes.
\end{abstract}

Keywords: disaster, disaster risk reduction, preparedness, landslide

\section{INTRODUCTION}

Landslides are one of the natural disasters that often occur in Indonesia.
Indonesia's disaster information data shows that between 2005-2015 Indonesia experienced more than 15,400 disaster events, $22 \%$ of which were geological disasters, one of which was landslides (BNPB, 2018). Research from the Center for Research on Epidemiology of Disaster (CRED) statistics show that landslides cause at least $17 \%$ severe damage at the level of world natural disasters (Charter, 1991 in Farhi et al., 2012).

If identified from the sliding motion of the material, landslides move faster than soil crawls, flowing soil, and flowing mud (Suharini, 2009). This shows the landslide occurred at a fast tempo. Of course, this is dangerous because there is very little time to save oneself. That is why preparedness is an urgent matter for people living in landslideprone areas.

Indonesian people need to have preparedness in dealing with disasters. Preparedness is all actions that allow all lines of society to respond to disaster situations quickly and effectively (Charter, 1991 in Farhi et al., 2012). The purpose of preparedness is to prepare the community to know the proper response when a disaster occurs. The family can be the right environment to shape this preparedness behavior.

Data on the Great Hanshin Awaji earthquake in 1995 showed that the percentage of survivors was caused by themselves by $35 \%$, family members $31.9 \%$, friends/neighbors $28.1 \%$, passers-by $2.60 \%$, SAR Team $1.70 \%$, and others $0.90 \%$ 

Village.

(Supartini et al., 2017). Based on these data, individuals play a very significant role in their safety. After the individual is the family. Family members have a big enough role in saving lives from disasters.

Sepakung Village is included in a landslide-prone area in Semarang Regency, Central Java. Prone to disaster, according to Law Number 24 Year 2007 is a series of physical and social conditions that increase the inability of the environment to reduce, prepare for a disaster. So that landslideprone areas can be identified through the physical and social conditions that exist in an area.

There are 12 sub-districts in Semarang Regency identified as landslideprone areas, one of which is Banyubiru District (DLH Semarang Regency, 2017). Banyubiru District is an administrative area where Sepakung Village is included in one of its areas. Geologically, Sepakung village has basaltic andesite rocks (Ramadhan et al., 2014). These rocks are easily weathered. The hilly topography also exacerbates this condition. It is miserable with the construction of settlements in areas prone to landslides. Of course, this will be a disaster that threatens the safety of the residents of Sepakung Village.

One of the causes of loss of life and damage/loss due to disasters is the lack of household preparedness (Ma'arif in Rante et al., 2012). Household preparedness needs to be strengthened, and the head of the household is very important here. According to Rante (2012), household preparedness is influenced by knowledge, experience in dealing with disasters, and disaster alert attitudes. This study will describe household preparedness seen from the variables of knowledge, experience in dealing with disasters, and attitude of vigilance. The purpose of this study is to describe household preparedness in Sepakung village, which incidentally is an area prone to landslides.

\section{MATERIALS \& METHODS}

This research is quantitative research using the percentage descriptive analysis technique and descriptive analysis. The descriptive percentage technique was used to analyze the variables of experience in dealing with disasters and attitude of vigilance, while descriptive analysis was used to analyze the knowledge variable. The population of this research is the residents of Sepakung village, totaling 4,358 people (BPS, 2019). The sampling technique was carried out purposively, namely the heads of families living around landslide-prone points in Sepakung Village, totaling 11 people.

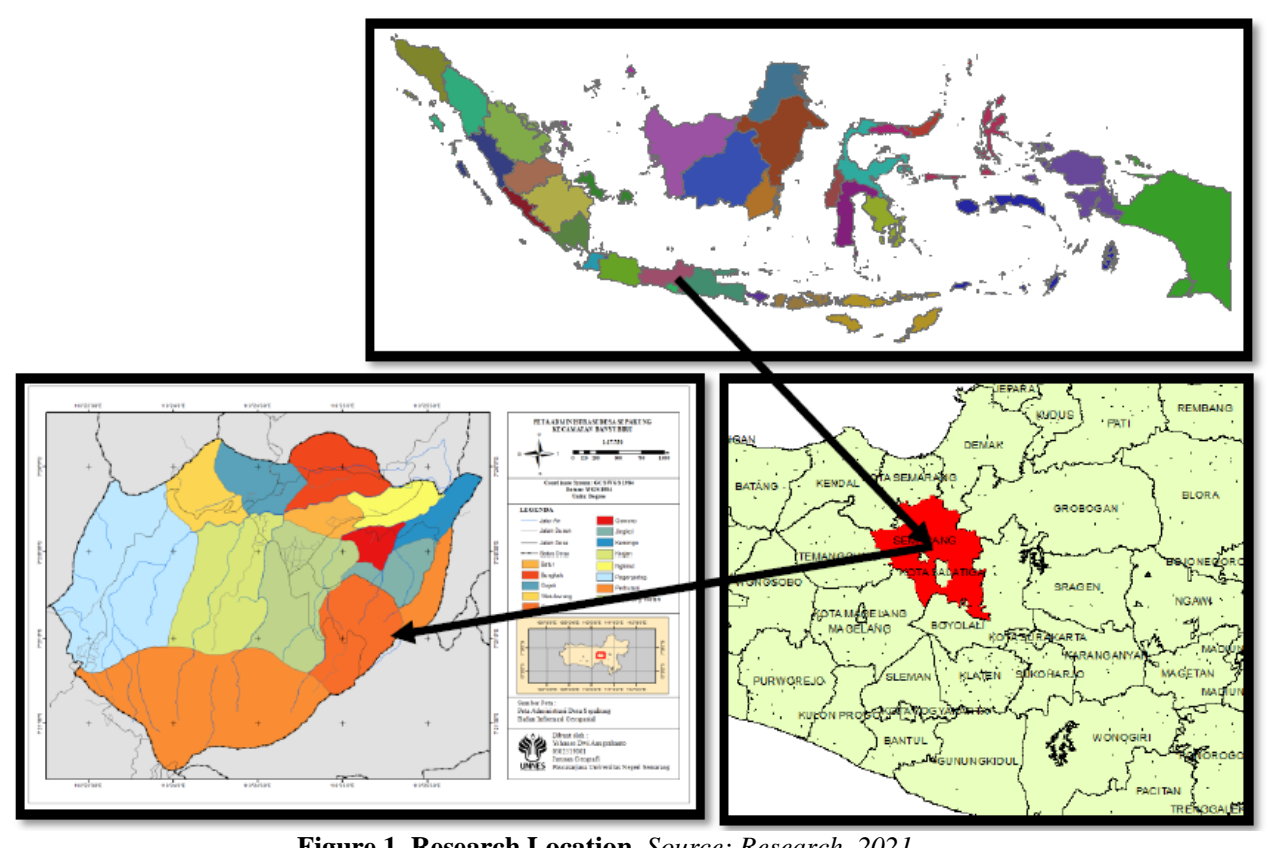

Figure 1. Research Location, Source: Research, 2021 
Data collection techniques in this study used observation, documentation, and questionnaires distributed to respondents. The observation technique was carried out to observe landslide-prone points in Sepakung Village. The results of observations of landslide-prone issues are the basis for determining respondents purposively. The questionnaire was used to determine the community's preparedness in mitigating landslides in Sepakung Village. Documentation is used to collect secondary data as supporting data.

\section{RESULT AND DISCUSSION}

\section{Experience Dealing with Disasters}

Experience is something that hits because you have experienced and did something in the past. The experience of dealing with disasters significantly influences preparedness (Havwina \& Maryani, 2016). According to Havwina (2016), the experience of dealing with disasters can be known through several indicators, including the experience of a person being directly affected by a disaster, the memory of a disaster, the presence of family members who are victims, living in disaster-prone areas. The parameters of the experience of landslides in this study were having experienced landslides directly, clearly remembering landslide events, experiencing losses due to landslides, learning from landslides.

Table 1. Experience in Dealing with Landslides

\begin{tabular}{|l|l|l|l|}
\hline \multicolumn{5}{|c|}{ Table 1. Experience in Dealing with Landslides } \\
\hline R & Score & DP $(\%)$ & Category \\
\hline R1 & 14 & 70 & Good \\
\hline R2 & 13 & 65 & Good \\
\hline R3 & 13 & 65 & Good \\
\hline R4 & 15 & 75 & Good \\
\hline R5 & 3 & 15 & Poor \\
\hline R6 & 20 & 100 & Very good \\
\hline R7 & 10 & 50 & Fair \\
\hline R8 & 14 & 70 & Good \\
\hline R9 & 16 & 80 & Good \\
\hline R10 & 13 & 65 & Good \\
\hline R11 & 14 & 70 & Good \\
\hline Average & 13.18 & 65.90 & Good \\
\hline
\end{tabular}

The data processing results show that the experience of dealing with landslides for the residents of Sepakung village is quite good. This is shown by the average descriptive percentage score reaching 65.909091. Most of the respondents in this study had experienced landslides, so it is not surprising that residents had good experiences with landslides. Ten respondents have experienced landslides out of a total of 11 respondents.

The ten respondents who had experienced landslides did not all remember the landslides they had experienced because one respondent chose not to answer. Most of the respondents still remember the landslides they have experienced. Respondents who have experienced landslides that have suffered heavy losses have reached seven people. In addition, there were three respondents whose family members were victims of the landslide. After experiencing a landslide, nine respondents knew what to do to avoid landslides.

Based on the results of data processing that researchers have done. So it can be seen if the experience of experiencing a landslide disaster can form awareness and knowledge of the residents who live around this landslide-prone point. This is evidenced by the presence of nine respondents who know what to do if a landslide occurs. They have a picture of surviving landslides, and this is a positive thing and can be strengthened through education.

\section{Disaster Alert Attitude}

According to Rante (2012), attitude is one of the most influential variables on household preparedness. The attitude of vigilance can reduce the number of casualties due to disasters (Nasarudin et al., 2020). The attitude of vigilance in this study can be seen through indicators that include adjustment to disaster-prone areas, protection of property, and protection of life safety (Nasarudin et al., 2020; BNPB, 2018; Raja et al., 2017). This indicator has been eliminated and adjusted to the target of the research respondents. 
Table 2. Disaster Alert Attitude

\begin{tabular}{|l|l|l|l|}
\hline R & Score & DP $(\boldsymbol{\%})$ & Category \\
\hline R1 & 19 & 95 & Very good \\
\hline R2 & 18 & 90 & Very good \\
\hline R3 & 17 & 85 & Very good \\
\hline R4 & 15 & 75 & Good \\
\hline R5 & 15 & 75 & Good \\
\hline R6 & 20 & 100 & Very good \\
\hline R7 & 15 & 75 & Good \\
\hline R8 & 19 & 95 & Very good \\
\hline R9 & 16 & 80 & Good \\
\hline R10 & 18 & 90 & Very good \\
\hline R11 & 15 & 75 & Good \\
\hline Average & 17 & 85 & Very good \\
\hline
\end{tabular}

The data processing results in table 2 describe the attitude of the respondent's alertness included in the very good category with a descriptive percentage score of $85 \%$. All respondents in this study agreed that awareness of landslides needs to be increased during the rainy season. The answers consist of five respondents agree, and six respondents strongly agree. Respondents have realized when is the right time to be aware of landslides, precisely when it rains.

All respondents know that they must be cover soil cracks with soil before the rainy season. The number of respondents who answered agree there are five people and strongly agree there are six people. They already understand that one of the triggers for landslides is rain. Cracked soil conditions will be very prone to landslides if water flows. A further step that can take is a periodic inspection of the soil condition accompanied by related parties. This intervention is also a form of education for residents in Sepakung village.

Respondents already understand well if suddenly water seepage appears, all family members need to be prepared for the possibility of landslides. This is indicated by the answers of respondents who mostly agree with the statement. A total of four respondents strongly agree, and seven other respondents agree. Seepage of water is another sign of impending landslides. It is essential to be aware of water seepage, and all respondents already have this attitude of vigilance.

Based on the data processing results that researchers have carried out, it shows that all respondents try to take turns awake at night during the rainy season. A total of three respondents strongly agree, and eight respondents answered agree. Taking turns being awake can be one of the best ways to survive an avalanche. In addition, this is also an essential social capital to take care of each other within the family. Because at night and the rainy season is undoubtedly a vulnerable time where people are resting. However, respondents have good vigilance by trying to be awake in turns.

All respondents agree that families need to be actively involved in patrol activities to monitor slope conditions in landslide-prone areas. A total of three respondents answered strongly agree, and eight respondents answered agree. The role of the family that the head of the family can represent is very important. The goal is for families to know the condition of the land near their homes. In addition to creating alertness can also create calm. This is because they know the soil condition so that they can anticipate the possibility of landslides early.

\section{Knowledge of Landslides}

There are six indicators to measure community disaster knowledge: disaster characteristics, early warning systems, evacuation facilities, evacuation routes, disaster experience, and disaster simulation (Patrisina et al., 2018). Will know knowledge in this study through aspects of knowledge of landslide disasters, knowledge of mitigation measures, knowledge of early warning systems, and knowledge of evacuation routes.

\subsection{Definition of Disaster}

A disaster is an event or series of events that threaten and disrupt people's lives and livelihoods caused by natural and/or non-natural factors and human factors that result in human casualties, environmental damage, property losses, and psychological impacts (Law Number 24 Year 2007). 
Yohanes Dwi Anugrahanto et.al. Household preparedness to reducing landslide disaster risk in Sepakung Village.

Table 3. Definition of Disaster

\begin{tabular}{|l|l|l|}
\hline R & \multicolumn{1}{|c|}{ Transcript } & \multicolumn{1}{|c|}{ Explicative theme } \\
\hline R1 & I don't know. It's been a landslide & $\begin{array}{l}\text { Know but can't explain in their } \\
\text { language }\end{array}$ \\
\hline R2 & Can not & Do not know \\
\hline R3 & Most of the disasters here are landslides. Twice a year. I want to build a road, but it's old & Know \\
\hline R4 & Do not know & Do not know \\
\hline R5 & Yes, disaster & Know \\
\hline R6 & $\begin{array}{l}\text { A disaster is an unwanted event (what happens) that happens to a person or area without our } \\
\text { knowledge }\end{array}$ & Know \\
\hline R7 & Do not understand & Do not know \\
\hline R8 & Yes, an incident that endangers the residents that come suddenly & Know \\
\hline R9 & You know, disaster is like an example, maybe a landslide, flood & $\begin{array}{l}\text { Know but can't explain in their } \\
\text { language }\end{array}$ \\
\hline R10 & Yes, it is a life-threatening incident & Know \\
\hline R11 & Events that threaten the safety of citizens & Know \\
\hline
\end{tabular}

The data processing results show that there are six respondents, or $54 \%$, who have been able to explain what a disaster is well; two respondents already know the definition of disaster but cannot explain it in their language. There are three or $27 \%$ of respondents who do not know what a disaster is. Some respondents already know the definition of a disaster well. Residents in Sepakung Village must understand disasters, so it is essential to form community knowledge.

\subsection{Definition of Landslide}

Landslide is the movement of slope material down and out of the slope due to the influence of gravity (Van Westen, et al., 2011 in Ruslanjari et al., 2020). Landslide is the movement of soil mass that moves down or out of the slope, following Van Westen's statement that gravity also provides a driving force for the slope-forming soil mass. Landslides are also one of the shapers of the earth's surface. Landslides, mass movements of rock, debris, or earth down a slope, are natural processes that have shaped much of the earth's landscape (Vasudevan \& Ramanathan, 2016).

Table 4 Definition of Landslide

\begin{tabular}{|l|l|l|}
\hline R & \multicolumn{1}{|c|}{ Transcript } & \multicolumn{1}{|c|}{ Explicative theme } \\
\hline R1 & I do not know. Yes, that once. I'll show you the location & Know \\
\hline R2 & Yes, I don't know, sir. I have no school education. & Know \\
\hline R3 & - & Do not know \\
\hline R4 & Do not know & Do not know \\
\hline R5 & Yes, I don't know & $\begin{array}{l}\text { Know but can't } \\
\text { explain }\end{array}$ \\
\hline R6 & How can I explain? I don't know, land (which cannot be described) & $\begin{array}{l}\text { Know but can't } \\
\text { explain }\end{array}$ \\
\hline R7 & The landslide disaster is like how the land on the slopes of the mountain that slides & Know \\
\hline R8 & Yes, the incident where the ground hit by water suddenly separated itself, finally there was a landslide & Know \\
\hline R9 & Landslides are landslides that fall & Know \\
\hline R10 & $\begin{array}{l}\text { Yes, landslides, because the soil is unstable and it rains continuously so that the unstable ground causes } \\
\text { landslides }\end{array}$ & Know \\
\hline R11 & Landslides are disasters, one of a kind natural disasters caused by moving ground & Know \\
\hline
\end{tabular}

Source: Data Processing, 2021

The data processing results show that seven or $64 \%$ of respondents know well what a landslide is. Two or $18 \%$ of respondents see a landslide but cannot explain what a landslide is. There are two or $18 \%$ of respondents who cannot explain what a landslide is. The data shows that most of the respondents already know what a landslide is. However, there are still a small number of respondents who do not know the definition of a landslide disaster. Villages need to pay attention to this so that the level of community knowledge about landslides can be increased. 

Village.

\subsection{Cause of Landslide}

The factors that cause landslides are (1) changes in slope gradient/slope angle and slope height naturally (vertical erosion) or artificially (cliff excavation); (2) overloaded with rock, soil, or other loads; (3) the presence of vibration or shaking by the earthquake; (4) rainfall and soil water content, increasing the rate of weathering of rocks which reduces cohesion; (5) the influence of vegetation, namely in the absorption of water content in the soil (Zaruba dan Mencl dalam Hariyanto \& Suharini, 2010). The combination of anthropogenic and natural factors is often the cause of landslides that take lives and property losses (Naryanto, 2011).

Table 5. Causes of Landslides

\begin{tabular}{|c|l|l|}
\hline R & \multicolumn{1}{|c|}{ Transcript } & Eplicative theme \\
\hline R1 & Usually trucks/motorcycles. The ground keeps moving, yes or what & Know \\
\hline R2 & Hmmm, don't you understand & Do not know \\
\hline R3 & Rainy season & Know \\
\hline R4 & Got rain & Know \\
\hline R5 & The forest is bare, and the land has water & Know \\
\hline R6 & Maybe because the soil can't hold much water & Know \\
\hline R7 & $\begin{array}{l}\text { It's already getting clear here, and it's not raining; when it rained heavily, it didn't even happen. If it's } \\
\text { getting clear, it's not raining down there; a landslide occurs }\end{array}$ & Know \\
\hline R8 & Barren land, heavy rain continues & Know \\
\hline R9 & The cause of the landslide disaster may be tree cutting, or there may not be a ditch & Know \\
\hline R10 & The rainy season, rainwater, unstable soil & Know \\
\hline R11 & $\begin{array}{l}\text { It's raining, the soil is bare, the soil is moving, and there are many plants in Bungkah, but specifically, it's } \\
\text { moving soil }\end{array}$ & Know \\
\hline
\end{tabular}

Source: Data Processing, 2021

Based on table 5, it can be seen that there are ten or $91 \%$ of respondents who know the cause of landslides, and there are one or $9 \%$ of respondents who do not know the cause of landslides. Respondents know the causes of landslides because some of them have experienced landslides. They explain the reasons for landslides based on their experiences. Most stated that landslides occurred because of rain, and only a tiny part explained the causes of landslides in human activities.

Knowledge of the causes of landslides is essential. The goal is to reduce the threat of landslides itself. Strengthening literacy is needed here so that residents can know that landslides are caused not only by natural factors but also by human factors.

\subsection{Landslide Disaster Time Often Happens}

A study conducted by Hasnawir (2012) in South Sulawesi shows that rainfall intensity above $50 \mathrm{~mm} /$ hour can cause shallow landslides that cause property damage, including loss of human life. The rainy season is a time to watch out for, especially for residents who live in landslide-prone areas.

Table 6. Landslide Disaster Time Often Happens

\begin{tabular}{|l|l|l|}
\hline R & Transkrip & Explicative Themes \\
\hline R1 & It was a long time, two years ago & $\begin{array}{l}\text { Does not answer } \\
\text { questions }\end{array}$ \\
\hline R2 & When it rains & Know \\
\hline R3 & Usually, during the rainy season & Know \\
\hline R4 & $\begin{array}{l}\text { Heavy rain. Usually, the rainy season is during the seventh or eighth month. If it rains a lot, it will be a } \\
\text { landslide }\end{array}$ & Know \\
\hline R5 & Rainy season & Know \\
\hline R6 & Usually, after the rain & Know \\
\hline R7 & Rain & Know \\
\hline R8 & December, January & Know \\
\hline R9 & Definitely during the rainy season & Know \\
\hline R10 & Usually December & Know \\
\hline R11 & It rained all night, so last night I was worried & Know \\
\hline
\end{tabular}

Source: Data Processing, 2021 

Village.

The data processing results show that as many as ten or $91 \%$ of respondents already know when landslides often occur, and one or $9 \%$ of respondents do not answer questions. Based on these data, respondents already have good knowledge about the time of the landslide disaster. This is a good capital because they can know when to be alert to landslides.

\subsection{Signs of a Landslide}

Signs of landslides in sloping areas include continuous heavy rain, seepage appears, cracks appear, the color of river water is cloudy if there is a potential for flash floods (BNPB, 2018). The signs of landslides need to be known by those who live in landslide-prone areas. Sepakung village has regions that are sloping, and landslides often occur with various scales.

Table 7. Signs of a Landslide

\begin{tabular}{|l|l|l|}
\hline R & Transkrip & $\begin{array}{l}\text { Explicative } \\
\text { Themes }\end{array}$ \\
\hline R1 & - & Do not know \\
\hline R2 & Do not know & Do not know \\
\hline R3 & - & Do not know \\
\hline R4 & Big rain & Know \\
\hline R5 & Cracked ground & Know \\
\hline R6 & Do not know & Do not know \\
\hline R7 & - & Do not know \\
\hline R8 & The signs are, yes, it rains continuously one day & Know \\
\hline R9 & The signs are usually the ground is swollen & Know \\
\hline R10 & The cracked ground keeps raining & Know \\
\hline R11 & $\begin{array}{l}\text { The signs, yes, there is ground movement, there is sound. I'm in the kitchen with my wife. Fasting is cooking. } \\
\text { A voice does not know what it is, and then my wife pulls it out here. My child was not born yet, so I kept } \\
\text { going back to the kitchen, just until the door there immediately collapsed. It's more or less } 4 \text { meters away } \\
\text { from me. I'm traumatized when I'm behind. Especially if it rains, it's not allowed in the kitchen }\end{array}$ & Know \\
\hline
\end{tabular}

Source: Data Processing, 2021

Based on table 7 above, we can see that the number of respondents who know the landslides is greater than those who do not know the signs of landslides. The number of respondents who know the signs of landslides is six or (55\%) respondents, while those who do not know are five or $45 \%$ of respondents. This data shows that knowledge about the signs of landslides by residents still needs to be considered again.

\subsection{Definition of disaster mitigation}

Mitigation is a variety of continuous efforts to reduce disaster risk through physical development, awareness, and capacity building to deal with disaster threats (Setyowati, 2019). Based on this statement, mitigation can increase the capacity of the community, so this is very important. Mitigation actions, if used early, will reduce the risk of natural disasters. This is because people of all ages know and implement disaster risk reduction efforts.

Table 8. Definition of disaster mitigation

\begin{tabular}{|l|l|l|}
\hline R & Transkrip & $\begin{array}{l}\text { Explicative } \\
\text { Themes }\end{array}$ \\
\hline R1 & - & Do not know \\
\hline R2 & No school education & Do not know \\
\hline R3 & $\begin{array}{l}\text { What is disaster management? For greenery, they are told to plant crops. Here, through the direction of the sub- } \\
\text { district, the guidelines from Perhutani are based on the slope of the land, how many degrees should not be a hoe, } \\
\text { only planted with wood. Villagers usually want to be alone. Instead of fighting, it's better to be silent. }\end{array}$ & $\begin{array}{l}\text { Do not know } \\
\text { R4 }\end{array}$ No school education \\
\hline R5 & Do not know & Do not know \\
\hline R6 & Do not know & Do not know \\
\hline R7 & Do not know & Do not know \\
\hline R8 & Do not know & Do not know \\
\hline R9 & What is mitigation? Plant trees, often ditch it because it's not a city. If it's in the town, maybe garbage, maybe yes & Do not know \\
\hline R10 & Do not know & Do not know \\
\hline R11 & Efforts to reduce the risk of landslides & Do not know \\
\hline
\end{tabular}

Source: Data Processing, 2021 

Village.

Based on the data processing results, most of the respondents do not know the definition of disaster mitigation. Ten or $91 \%$ of respondents do not know what disaster mitigation is. There are only one or $9 \%$ of respondents who know the definition of disaster mitigation well. This is because these respondents often attend disaster training conducted by BPBD. This proves that the educational process is critical to increasing public knowledge.

\subsection{Early Warning System}

Developing a community-based early warning system aims to empower individuals and communities at risk to act in sufficient time and inappropriate ways to reduce the possibility of injury, loss of life, and damage to property and the environment (BNPB, 2012). An early warning system can be effective if residents also know the meaning and purpose of the existence of the early warning system.

Table 9. Early Warning System

\begin{tabular}{|l|l|l|}
\hline R & Transkrip & $\begin{array}{l}\text { Explicative } \\
\text { Themes }\end{array}$ \\
\hline R1 & - & Do not know \\
\hline R2 & Do not know & Do not know \\
\hline R3 & Do not know & Do not know \\
\hline R4 & Do not know & Do not know \\
\hline R5 & Do not know & Do not know \\
\hline R6 & Early warning what that means. It's good to be aware of disasters & Know \\
\hline R7 & Do not know & Do not know \\
\hline R8 & Warning to know the signs of a disaster event & Know \\
\hline R9 & The benefits may be preparation & Know \\
\hline R10 & Usually, there are announcements, warnings to the public. Yes announcement & Do not know \\
\hline R11 & $\begin{array}{l}\text { Already. Its function is to alert residents when there is ground movement before a disaster occurs. There's one } \\
\text { in Bungkah. If it's not in Srandil yet }\end{array}$ & Know \\
\hline
\end{tabular}

Source: Data Processing, 2021

The data processing results in table 9 show that more respondents do not know the function of the early warning system. Seven or $64 \%$ of respondents do not know, and four or $36 \%$ of respondents already know the function of the early warning system. This could be because there is only one hamlet that has an early warning system. The other village does not yet have an early warning system.

\subsection{Evacuation Route}

Evacuation routes are one form of structural mitigation that needs to be in disaster-prone areas. In addition to the availability of evacuation routes, residents must also understand the concept of the evacuation route itself. Understanding the evacuation route will provide residents with knowledge to make the evacuation route's function more effective.

\begin{tabular}{|l|l|l|}
\hline \multicolumn{3}{|c}{ Table 10. Evacuation Route } \\
\hline R & Transkrip & $\begin{array}{l}\text { Explicative } \\
\text { Themes }\end{array}$ \\
\hline R1 & - & Do not know \\
\hline R2 & How to explain? Emergency road & Know \\
\hline R3 & Do not know & Do not know \\
\hline R4 & Do not know & Do not know \\
\hline R5 & Do not know & Do not know \\
\hline R6 & Pass & Do not know \\
\hline R7 & Do not know & Do not know \\
\hline R8 & $\begin{array}{l}\text { That evacuation route, that route, the } \\
\text { hazard route }\end{array}$ & Do not know \\
\hline R9 & Self-rescue path & Know \\
\hline R10 & Do not know & Do not know \\
\hline R11 & $\begin{array}{l}\text { Paths to pass by residents who want to } \\
\text { save themselves }\end{array}$ & Know \\
\hline \multicolumn{2}{|c|}{ Source: Data Processing, 2021} \\
\hline
\end{tabular}

Based on the data processing results in table 10, most of the respondents do not know an evacuation route. The number of respondents who do not know is eight or $72 \%$ of respondents and only three or $28 \%$ of respondents who know the evacuation route. Knowledge of evacuation routes still needs to be improved. 


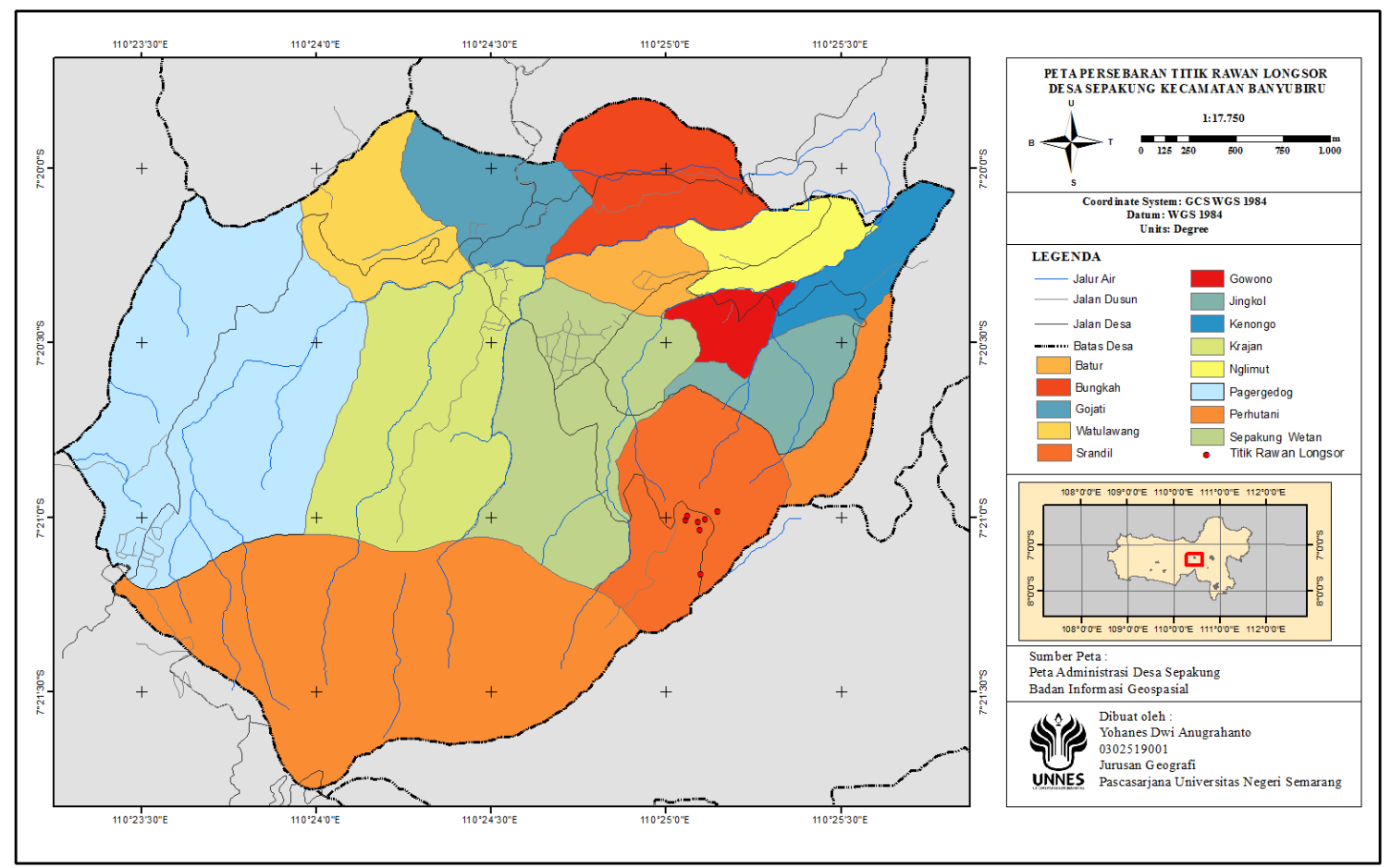

Figure 2. The Distribution Map of Landslide-prone Points in Sepakung Village Source: Data Processing, 2021

\section{CONCLUSION}

The residents of Sepakung Village already have experience in dealing with disasters which are categorized as good. This experience can be an essential capital to survive the landslide disaster. In addition, the attitude of vigilance of the residents of Sepakung Village is also very good. They already know what to do to reduce the risk of landslides. Knowledge of landslides needs to be increased again, especially about the signs of landslides, disaster mitigation, early warning systems, and evacuation routes. Increased knowledge can be done in various ways, be it training, counseling, or other forms of education. It is hoped that the family can become a disaster education environment, especially related to landslides.

\section{Acknowledgement: None}

\section{Conflict of Interest: None}

Source of Funding: None

\section{REFERENCES}

1. BNPB. (2012). Pedoman Sistem Peringatan Dini Berbasis Masyarakat. Direktorat Kesiapsiagaan BNPB.

2. BNPB. (2018). Panduan Kesiapsiagaan Bencana Untuk Keluarga. Direktorat Kesiapsiagaan BNPB.

3. BPS. (2019). Kecamatan Banyubiru Dalam Angka 2019. In Kecamatan Banyubiru Dalam Angka 2019 (2019th ed., pp. 1-48). Badan Pusat Statistik Kabupaten Semarang.

4. DLH. (2017). Laporan Informasi Kinerja Pengelolaan Lingkungan Hidup (Issue 29). DLH Kabupaten Semarang.

5. Farhi, Z., Sudibyakto, \& Hadmoko, D. S. (2012). Tingkat Kerentanan Dan Indeks Kesiapsiagaan Masyarakat Terhadap Bencana Tanah Longsor Di Kecamatan Bantarkawung Kabupaten Brebes. Majalah Geografi Indonesia, 26(1), 80-97. https://doi.org/10.22146/mgi.13406

6. Hariyanto, \& Suharini, E. (2010). Preferensi Permukiman dan Antisipasi Penduduk yang Tinggal di Daerah Rawan Longsor di Kota Semarang. Jurnal Geografi, 3(1), 204-215. https://journal.unnes.ac.id/nju/index.php/JG/ article/view/93

7. Hasnawir. (2012). Intensitas Curah Hujan Memicu Tanah Longsor Dangkal di Sulawesi Selatan. 1(1), 62-73. https://media.neliti.com/media/publications/ 
123118-ID-intensitas-curah-hujan-memicutanah-long.pdf

8. Havwina, T., \& Maryani, E. (2016). Pengaruh Pengalaman Bencana Terhadap Ancaman Gempabumi Dan Tsunami (Studi kasus pada SMA Negeri Siaga Bencana Kota Banda Aceh ). 16, 124-131.

9. Naryanto, H. S. (2011). Analisis Resiko Bencana Tanah Longsor di Kabupaten Karanganyar, Provinsi Jawa Tengah. Jurnal Penanggulangan Bencana, 4(1), 21-32. https://media.neliti.com/media/publications/ 132656-ID-analisis-kondisi-bawahpermukaan-dan-ris.pdf

10. Nasarudin, N., Kasnar, S., \& Suwo, R. (2020). Analisis Kesiapsiagaan Rumah Tangga Kelurahan Tubo Terhadap Banjir Lahar Dingin Di Sungai Tugurara Ternate. Tunas Geografi, 8(2), 123. https://doi.org/10.24114/tgeo.v8i2.14958

11. Patrisina, R., Emetia, F., Sirivongpaisal, N., Suthummanon, S., Alfadhlani, A., \& Fatrias, D. (2018). Key performance indicators of disaster preparedness: A case study of a tsunami disaster. MATEC Web of Conferences, 229. https://doi.org/10.1051/matecconf/20182290 1010

12. Raja, Z. D. G., Hendarmawan, H., \& Sunardi, S. (2017). Kajian Upaya Pengurangan Risiko Dan Kesiapsiagaan Masyarakat Terhadap Ancaman Bencana Tanah Longsor (Desa Ndito Kecamatan Detusoko Kabupaten Ende Provinsi Nusa Tenggara Timur ). Jurnal Lingkungan Dan Bencana Geologi, 8(2), 103-116. https://doi.org/10.34126/jlbg.v8i2.176

13. Ramadhan, N., Prameswari, M., \& Harijoko, A. (2014). Evaluasi Kondisi Geologi dan Geokimia Potensi Panasbumi Guungapi Telomoyo. Prosiding Seminar Nasional Kebumian Ke-7, 447-458. https://repository.ugm.ac.id/135149/1/447458 M2P-05.pdf

14. Rante, A., Mantu, F. N., \& Patellongi, I. (2012). Tingkat Kesiapsiagaan Rumah Tangga Menghadapi Bencana Alam Tanah Lonsor di Kelurahan Battang Barat Kecamatan Wara Barat Kota Palopo Tahun 2012.
15. Ruslanjari, D., Permana, R. S., \& Wardhana, F. (2020). Kondisi Kerentanan dan Ketahanan Masyarakat Terhadap Bencana Tanah Longsor di Desa Pagerharjo , Kecamatan Samigaluh , Kabupaten Berdasarkan Data dan Informasi Bencana Nglinggo Barat dan Nglinggo Timur juga wisata berupa Wisata Edukasi Kehidupan Bukit Ngis. Jurnal Ketahanan Nasional, 26(1), 23-39. http://dx.doi.org/ $10.22146 / \mathrm{jkn} .54415$

16. Setyowati, D. L. (2019). Pendidikan Kebencanaan. In Urgensi Pendidikan Mitigasi Bencana. Universitas Negeri Semarang.

17. Suharini, E. dan A. P. (2009). Geomorfologi: Gaya, Proses, dan Bentuk Lahan (D. L. Setyowati (ed.)). Widya Karya.

18. Supartini, E., Kumalasari, N., Andry, D., Susilastuti, Fitrianasari, I., Tarigan, J., Haryanta, A. A., \& Nugi, R. (2017). Membangun Kesadaran,Kewaspadaan, dan Kesiapsiagaan dalam Menghadapi Bencana. In Buku Pedoman Latihan Kesiapsiagaan Bencana (Vol. 1, Issue 1). Direktorat Kesiapsiagaan Deputi Bidang Pencegahan dan Kesiapsiagaan BNPB. https://siaga.bnpb.go.id/hkb/pocontent/uploads/documents/buku_panduan_1 atihan_kesiapsiagaan_bencana_revisi_april_ 2017.pdf

19. UU No. 24 Tahun 2007 Tentang Penanggulangan Bencana, 1. https://peraturan.bpk.go.id/Home/Details/39 901/uu-no-24-tahun-2007

20. Vasudevan, N., \& Ramanathan, K. (2016). Geological factors contributing to landslides: Case studies of a few landslides in different regions of India. IOP Conference Series: Earth and Environmental Science, 30(1), 1-6. https://doi.org/10.1088/1755$1315 / 30 / 1 / 012011$

How to cite this article: Anugrahanto YD, Setyowati DL, Suharini E. Household preparedness to reducing landslide disaster risk in Sepakung Village. International Journal of Research and Review. 2021; 8(8): 618-627. DOI: https://doi.org/10.52403/ijrr.20210882 